(C) The Author(s), 2021. Published by Cambridge University Press for the Arizona Board of Regents on behalf of the University of Arizona. This is an Open Access article, distributed under the terms of the Creative Commons Attribution licence (https://creativecommons.org/licenses/by/4.0/), which permits unrestricted re-use, distribution, and reproduction in any medium, provided the original work is properly cited.

\title{
FTIR BONE CHARACTERIZATION AND RADIOCARBON DATING: TIMING THE ABANDONMENT OF BYZANTINE PIGEON TOWERS IN THE NEGEV DESERT, ISRAEL
}

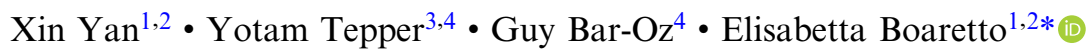 \\ ${ }^{1}$ Kimmel Center for Archaeological Science, Weizmann Institute of Science, Rehovot 76100, Israel \\ ${ }^{2}$ D-REAMS Radiocarbon Laboratory, Scientific Archaeology Unit, Weizmann Institute of Science, Rehovot, 76100, \\ Israel \\ ${ }^{3}$ Archaeological Division, The Israel Antiquities Authority, Tel Aviv, 61012, Israel \\ ${ }^{4}$ Zinman Institute of Archaeology, University of Haifa, Haifa, 3498838, Israel
}

\begin{abstract}
Various archaeological and historical evidence shows that the marginal area of the Negev desert of southern Israel enjoyed great agricultural prosperity in the Byzantine period (4th-7th centuries CE). Among the different types of agricultural installations are pigeon towers, which were built near the fields to produce fertilizer to enrich the nutrient-poor desert soils. Such extensive specialized agriculture practice was much less applied in the Negev in the successive Early Islamic period in the mid-7th century. Here we recovered in situ pigeon bones from five pigeon towers in the Negev, applied multiple characterization methods (FTIR, grinding curve, and C/N ratio) to estimate the preservation of bones, and achieved absolute dating for the abandonment of the towers. The obtained dates indicate rapid decline of agricultural activities in the second half of the 6th century CE and beginning of the 7 th century. These findings, together with other evidence for Byzantine decline of agricultural hinterland and urban dysfunction of the settlements, suggest that the farming activities in the Negev declined in the Late Byzantine period (550-640 CE) and support the hypothesis that climatic-driven causes were the main trigger for the eventual cultural-societal decline of the Negev region.
\end{abstract}

KEYWORDS: Byzantine archaeology, climate change, pigeon tower, radiocarbon dating, splitting factor.

\section{INTRODUCTION}

The cultural landscape around the Byzantine sites of the Negev desert of southern Israel (4th7th centuries CE) preserves abundant evidence for intensive farming activities in arid region, including dams, cisterns, wine presses and agricultural installations. These remains are vivid evidence to the sophisticated farming technologies exploited in Late Antiquity within an environmentally marginal, challenging arid environment. The Byzantine florescence of the Negev reached its peak during the 5th-6th centuries CE, and was followed by the Islamic conquest of the southern Levant in the mid-7th century and decline of circumMediterranean trade networks linking Europe and the Levant (McCormick 2001; Magness 2003; Hirschfeld 2006; Avni 2014; Harper 2017). The most pronounced evidence for societal collapse is found in the settlements of Shivta and Elusa, where abandonment and reduced activity have been clearly documented. Shivta is dominated by ample numbers of deserted houses, many of which had their doors sealed since antiquity (Tepper et al. 2015, 2018a). Decline was also noted in the agricultural hinterlands of the villages of Shivta and Sa'adon, as evident from the abandonment of several pigeon towers at the end of the Byzantine period (Hirschfeld and Tepper 2006; Ramsay et al. 2016; Tepper et al. 2018b). Likewise, multi-disciplinary archaeological investigations of trash management organizations in the nearby Byzantine city of Elusa showed that major urban decline had occurred already a century before the Islamic transitions (Bar-Oz et al. 2019).

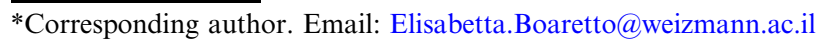


Free-standing pigeon towers are key features of the agricultural landscape all over the region from the Hellenistic to Byzantine period, which spread to the Negev Highlands during Late Roman period and reached its peak during the Byzantine period (Tepper 1986, 2007a; Hirschfeld and Tepper 2006; Tepper et al. 2017). Their excavations with rich biological remains of pigeon bones and abundant of plant remains and nesting material indicate the center of farming to the Negev Byzantine lifestyle and the intensive agronomic practice that relied primarily on vineyards and orchard plantations (Tepper 2007b; Fried et al. 2018; Marom et al. 2018; Tepper et al. 2020).

The Byzantine pigeon towers are situated today in the marginal area of the Negev, around or to the south of the $200 \mathrm{~mm}$ precipitation isohyet (Dody and Ziv 2013), in a difficult environment condition for agricultural practice. Three of these pigeon towers (Sa'adon Building B, Shivta Buildings 2 and 6) are located within the hinterland of the 5th-6th century villages of Sa'adon and Shivta. Two more pigeon towers, Be'er Sheva Zoological Garden and Rova Noy are related to Byzantine farms around the Byzantine site of Be'er Sheva (Gil'ad and Fabian 2008; Haiman et al. 2020). Findings in all pigeon towers include pigeon bones, and in Shivta Building 6 and Sa'adon Building B, rich dung layers with plant remains, eggshells and pigeon droppings were also recovered on top of the floors.

Among the numerous pigeon bones yielded from excavations of the pigeon towers, some were found in articulation in situ. Their remains indicate that the pigeons inhabiting the towers were of a small, wild-type morphology, and appear to have been part of the local pool of the wild rock pigeon (Columba livia; Marom et al. 2018). Their small size suggests that the birds were raised primarily for their manure, to enrich the poor-nutrient loess soil of the Negev, and not for their meat. This manure was an excellent organic fertilizer, as testified by Varro (Rerum Rusticarum III: VII, see Varro 1934), Columella (De Re Rustica VIII, 3-5, see Columella 1941), and Pliny the Elder (Naturalis Historia X, 53; see Pliny the Elder 1952, 2021). Archaeozoological studies of bones from the Negev sites found that only $0.5 \%$ of the entire faunal assemblage is comprised of pigeon bones (Marom et al. 2019), supporting that pigeons were not bred for food as primary goal (Hirschfeld and Tepper 2006).

Due to their key role for sustaining agriculture in the poor soil, determining the exact timing of the activity of each of the pigeon towers in the Negev is crucial for understanding the dynamics of Byzantine agricultural and societal decline. If the last occupation of the pigeon towers has been a synchronized phenomenon, it would speak for a rapid process that occurred in a narrow period of time and would provide a solid framework for the time window during which it occurred. Alternatively, if the dates of abandonment of the pigeon towers stretch over a long period of time, it will show that the desertion of the pigeon towers was not simultaneous and was a more gradual and continuous process, calling for local-level, mosaic interpretations.

To test the opposing hypotheses of synchronous versus gradual abandonment, we obtained dates of pigeon bones from the last archaeological living floor which accumulated in five pigeon towers that are dispersed across the Byzantine Negev hinterland (Figure 1). Together, they enable us to examine the synchrony of pigeon towers' abandonment and to substantiate or refute the scenario of sharp and overall decline of the Byzantine agricultural landscape. We conducted radiocarbon $\left({ }^{14} \mathrm{C}\right)$ dating of eight pigeon bones uncovered from the five pigeon towers. In previous studies on the pigeon towers, three ${ }^{14} \mathrm{C}$ dates have been published: pigeon dung from Shivta Building 6 (430-605 cal CE; Ramsay et al. 2016), three 

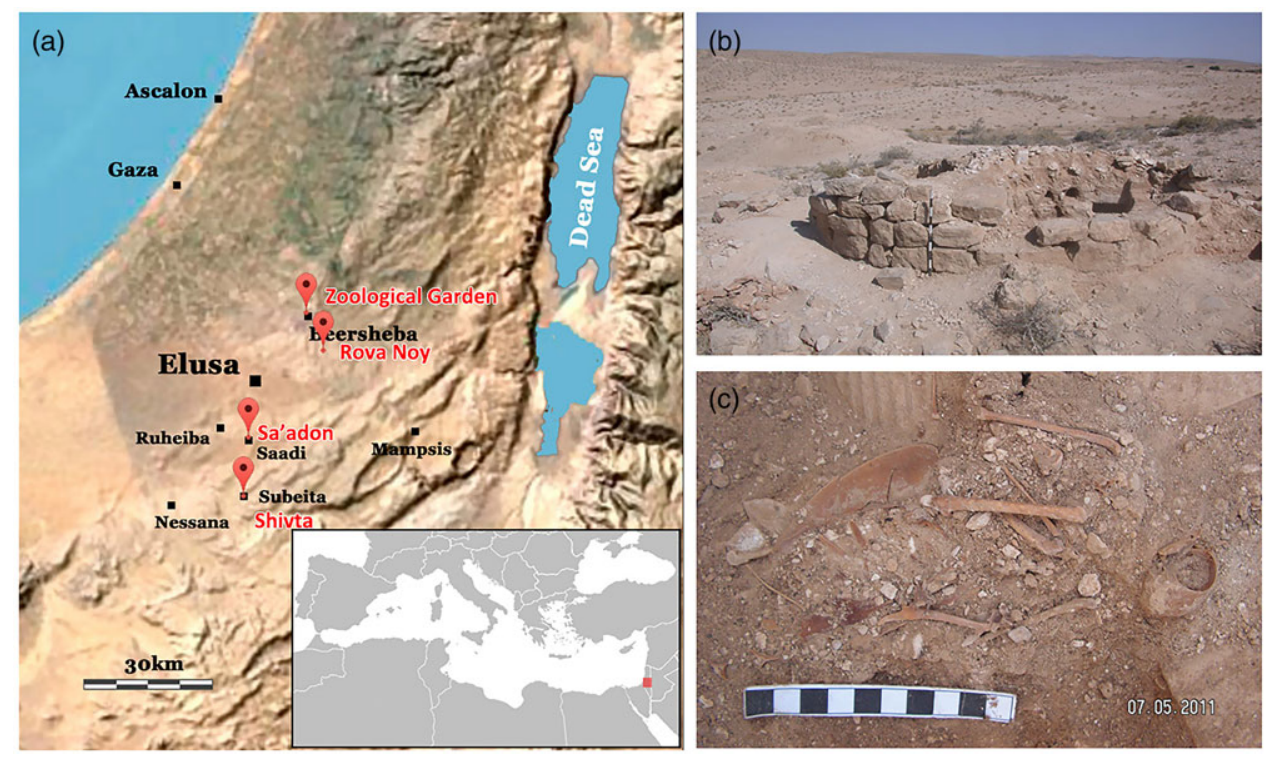

Figure 1 (a) Location of the Negev Desert (red square in inset map) related to the Mediterranean, and archaeological sites with pigeon towers; (b) pigeon tower no. 6 at Shivta, photo by Yotam Tepper; (c) pigeon bones in articulation in Sa'adon pigeon tower B, photo by Yotam Tepper. (Please see electronic version for color figures.)

pigeon bones from Sa'adon Building B (Tepper et al. 2018b, also reported in this paper) and a piece of wood from Shivta Building 2 (RT 3983, $1745 \pm 45$ BP, 245-365 cal CE 68.3\% probability; Hirschfeld and Tepper 2006). In this study, we extend the pigeon bone dating in Sa'adon to four more pigeon towers in the Negev. The combined dates presented below provide the critical mass needed to examine the stages and represent an accurate dataset for this long-debated eventual decline.

\section{SITE DESCRIPTIONS}

Locations of sites with pigeon towers, and pigeon bones found in articulation in situ are shown in Figure 1. A summary of the pigeon towers investigated in this study and associated findings is listed in Table 1, followed by detailed descriptions of each pigeon tower and each dated pigeon bone.

The size of each of these installations indicate that they could subsist a few hundred individuals and thus provide hundreds of liters of condense and highly valuable manure annually (Hirschfeld and Tepper 2006). Detailed descriptions of each dated site are as follows:

\section{Shivta}

Four pigeon towers have been excavated around the village of Shivta (Hirschfeld and Tepper 2006), three of them being circular (Buildings 1, 2, and 6) and one being rectangular (Building 4). Pigeon bones dated in this study were from building no. 2 and building no. 6 .

Building no. 2 has an outer diameter of $9.5 \mathrm{~m}$, inner diameter of $6.5 \mathrm{~m}$, and a remaining height of $0.3-0.5 \mathrm{~m}$. The inner part is divided by two inner walls into four rooms. Pottery sherds from Roman to Early Islamic period were found at the upper debris and accumulations layers as well 
Table 1 List of pigeon towers that yielded pigeon bones dated in this study.

\begin{tabular}{|c|c|c|c|c|}
\hline Name of site & $\begin{array}{l}\text { Type of } \\
\text { pigeon tower }\end{array}$ & $\begin{array}{l}\text { Size and } \\
\text { structure }\end{array}$ & Main findings & Reference \\
\hline \multirow[t]{2}{*}{ Shivta } & $\begin{array}{l}\text { Building 2: } \\
\text { Circular }\end{array}$ & $\begin{array}{l}\text { Outer diameter: } \\
9.5 \text { m, inner } \\
\text { diameter: } 6.5 \\
\text { m; divided by } 2 \\
\text { walls into } 4 \\
\text { rooms }\end{array}$ & $\begin{array}{l}\text { Roman, Byzantine, } \\
\text { Early Islamic } \\
\text { pottery sherds }\end{array}$ & $\begin{array}{l}\text { Hirschfeld and } \\
\text { Tepper (2006) }\end{array}$ \\
\hline & $\begin{array}{c}\text { Building 6: } \\
\text { Circular }\end{array}$ & $\begin{array}{l}\text { Outer diameter: } \\
5.5 \text { m, inner } \\
\text { diameter: } 3.5 \\
\text { m; divided by } 3 \\
\text { walls into } 3 \\
\text { rooms }\end{array}$ & $\begin{array}{l}\text { Plants seeds, plant } \\
\text { remains, pigeon } \\
\text { bones, pigeon } \\
\text { droppings }\end{array}$ & $\begin{array}{l}\text { Ramsay et al. } \\
\text { (2016) }\end{array}$ \\
\hline Sa'adon & $\begin{array}{l}\text { Building B: } \\
\text { Rectangular }\end{array}$ & $\begin{array}{l}4.0 \mathrm{~m} \times 4.0 \mathrm{~m} \text {; } \\
\text { divided by one } \\
\text { inner wall into } \\
2 \text { rooms }\end{array}$ & $\begin{array}{l}\text { Byzantine pottery } \\
\text { sherds; rodent } \\
\text { bones, Plants } \\
\text { seeds, plant } \\
\text { remains, pigeon } \\
\text { bones, pigeon } \\
\text { droppings }\end{array}$ & $\begin{array}{l}\text { Tepper et al. } \\
\text { (2018b) }\end{array}$ \\
\hline $\begin{array}{l}\text { Be'er Sheva the } \\
\text { Zoological } \\
\text { Garden }\end{array}$ & Circular & $\begin{array}{l}\text { Outer diameter: } \\
9.0 \text { m, inner } \\
\text { diameter: } 7.5 \\
\text { m; divided by } 2 \\
\text { walls into } 4 \\
\text { rooms }\end{array}$ & $\begin{array}{l}\text { Byzantine, Early } \\
\text { Islamic pottery } \\
\text { sherds; pigeon } \\
\text { bones }\end{array}$ & $\begin{array}{l}\text { Kobrin and } \\
\text { Tepper }(2017)\end{array}$ \\
\hline Rova Noy & Circular & $\begin{array}{l}\text { Inner diameter: } \\
4.2 \text { m; divided } \\
\text { by } 2 \text { walls into } \\
2 \text { rooms }\end{array}$ & $\begin{array}{l}\text { Byzantine pottery } \\
\text { sherds; pigeon } \\
\text { bones }\end{array}$ & $\begin{array}{l}\text { Eisenberg- } \\
\text { Degen (2017) }\end{array}$ \\
\hline
\end{tabular}

as large amount of organic materials. A few dozens of pigeon bones were found on the floor layer only, including a large wood beam of Cedrus lebani. The installation was robbed after the Byzantine period when probably some Early Islamic pottery was left. A fragment of a pigeon femur bone (ca. $3.0 \mathrm{~cm}$ long) from above the floor (L 207) was selected for ${ }^{14} \mathrm{C}$ dating.

Building no. 6 has an outer diameter of $5.5 \mathrm{~m}$, inner diameter of $3.5 \mathrm{~m}$, and a remaining height of $1.2 \mathrm{~m}$. The inner space is divided by Y shaped walls into three rooms. Pottery sherds dating to the 6th century CE, as well as large amount of organic materials including wood branches and pigeon bones have been recovered in the dung layer. Two fragments of a pigeon ulna bones (ca. $4.5 \mathrm{~cm}$ long each) have been selected for ${ }^{14} \mathrm{C}$ dating, both from the dung layers in different rooms (L 814 and L 817).

Building no. 6 might have been destroyed in a violent event, as the architectural remains were found in debris, the paraphernal wall was found destroyed and some of the large wall stones 
were moved from their place. According to our understandings, such findings attest to sudden and violent abandonment (Hirschfeld and Tepper 2006).

\section{Sa'adon}

Two pigeon towers, a round structure (Building A) and a square-shaped structure (Building B), near the village of Sa'adon were excavated (Tepper et al. 2018b). The pigeon bones of this study were recovered from Building $\mathrm{B}, \mathrm{a} 4.0 \mathrm{~m} \times 4.0 \mathrm{~m}$ rectangular structure with remaining height of about $1.0 \mathrm{~m}$. An internal wall divides the structure into two chambers. Byzantine pottery sherds, ceramic pipes together with large quantities of organic remains including seeds, charcoals, pigeon bones, and pigeon eggshells were recovered from the dung layer on top of the floor. Three pigeon bones were selected for ${ }^{14} \mathrm{C}$ dating, all from the dung layer above the floor: one femur (ca. $3.5 \mathrm{~cm}$ long) from L 212, one synsarcum (ca. $3.5 \mathrm{~cm}$ long) from L 213, and one radius (ca. $4.5 \mathrm{~cm}$ long) from L 213.

\section{Be'er Sheva Zoological Garden}

A circular structure, with inner diameter $7.5 \mathrm{~m}$, outer diameter $9 \mathrm{~m}$, and remaining height of no more than 0.2-0.4 $\mathrm{m}$ has been found at Be'er Sheva Zoological Garden (Kobrin and Tepper 2017). Two intersecting internal walls divide the structure into four rooms, and one of them (L 105) was excavated entirely, revealing Late Byzantine and Early Islamic ceramics mixed with the debris and accumulations layers of the structure. Pigeon bones have been found on the floor layer only. The installation was robbed after the Byzantine period when probably some Early Islamic pottery was left. One humerus bone of pigeon $\left(3.5 \mathrm{~cm}\right.$ long) was selected for ${ }^{14} \mathrm{C}$ dating.

\section{Rova Noy (Be'er Sheva South)}

Rova Noy, or Be'er Sheva South contains a circular structure of inner diameter $4.2 \mathrm{~m}$, and remaining height of $0.4-0.5 \mathrm{~m}$ (Eisenberg-Degen 2017). The structure was built of chalk and was divided by two interior walls into two rooms. Organic materials including pigeon bones and pigeon eggshells were revealed upon the floor, and a fragment of pigeon tibiobarsus bone (ca $2.0 \mathrm{~cm}$ long) was selected for ${ }^{14} \mathrm{C}$ dating.

Among all of the pigeon towers mentioned above, the best-preserved buildings are Sa'adon Building B and Shivta Building no. 6. They preserve a life layer of rich botanical finds including pigeon's bones on their floors. This layer, in both towers, was sealed by collapse from an abrupt event during abandonment. The other installations were less well preserved, and probably have been rubbed of their building stones and other raw materials throughout the years, probably during the Early Islamic period.

\section{METHODS}

\section{Prescreening}

Eight bones from five pigeon towers, excavated in four archaeological sites were selected for ${ }^{14} \mathrm{C}$ dating.

Initially the bones were submitted to the prescreening procedures at the D-REAMS ${ }^{14} \mathrm{C}$ laboratory (Weizmann Institute) following the preparation procedure in (Boaretto et al. 2009). Fourier transform infrared (FTIR) spectroscopy was applied on untreated bone powder and acid insoluble fraction to determine the presence of collagen. The acquired 
FTIR spectra are analyzed with the reference of standards library of the Kimmel Center for Archaeological Science, Weizmann Institute (http://www.weizmann.ac.il/kimmel-arch/ infrared-spectra-library). FTIR analysis provides the composition of the material and its changes due to physical and chemical process (Weiner 2010). Infrared splitting factor (IRSF) is calculated from the FTIR spectra, evaluating the crystallinity of carbonate hydroxylapatite crystals, which is related to the diagenesis of the bone mineral. The splitting factor of modern bone mineral ranges between 2.5 and 2.9 (Weiner and Bar-Yosef 1990). Percentage of collagen was estimated by the weight of the acid insoluble fraction divided by the weight of bone powder before acid dissolution. FTIR spectra of acid insoluble fraction were used to qualitatively estimate the preservation of bone collagen and screen for possible contaminants. Samples with spectra indicating well-preserved collagen were selected for ${ }^{14} \mathrm{C}$ dating.

\section{Collagen Extraction}

Bone collagen was purified for ${ }^{14} \mathrm{C}$ dating using acid-base-acid procedure, followed by gelatinization and ultrafiltration (Yizhaq et al. 2005; Brock et al. 2010). For each sample, between 100 and $200 \mathrm{mg}$ of bone powder was treated with $0.5 \mathrm{~N} \mathrm{HCl}$ until the mineral was completely dissolved (ca. $1 \mathrm{hr}$ ) and then rinsed with nanopure water several times until $\mathrm{pH}=7$. Then the samples received $0.1 \mathrm{~N} \mathrm{NaOH}$ treatment for $30 \mathrm{~min}$ and were rinsed with nanopure water until $\mathrm{pH}=7$. A final acid treatment of $0.5 \mathrm{~N} \mathrm{HCl}$ for $5 \mathrm{~min}$ was followed by rinsing with nanopure water until $\mathrm{pH}=3$. Suspensions were gelatinized at $70^{\circ} \mathrm{C}$ for $20 \mathrm{hr}$, and then passed through polyethylene filters (Ezee-filter ${ }^{\mathrm{TM}}$ ) and ultrafilters (Vivaspin ${ }^{\mathrm{TM}} 15$, 30kD MWCO), both filters being precleaned by established procedures (Brock et al. 2007). The extracted gelatin sample is examined with FTIR for purity determination (Yizhaq et al. 2005).

\section{Graphitization and Measurement}

Purified gelatin samples were lyophilized for $24 \mathrm{hr}$ and combusted with ca. $200 \mathrm{mg} \mathrm{CuO}$ in vacuum sealed quartz tubes. The produced $\mathrm{CO}_{2}$ was reduced to graphite on Fe powder as catalyst, and in the presence of $\mathrm{H}_{2}$ gas at $560{ }^{\circ} \mathrm{C}$ for $10 \mathrm{hr}$ (Goldenberg et al. 2017). Graphite samples were measured by accelerator mass spectrometry (AMS) at the D-REAMS radiocarbon laboratory (Regev et al. 2017) and reported as ${ }^{14} \mathrm{C}$ years $\left({ }^{14} \mathrm{C}\right.$ date, years $\left.\mathrm{BP}\right)$. The calibrated ranges were determined using the OxCal 4.4.1 (Bronk Ramsey and Lee 2013) with the calibration curve IntCal 20 (Reimer et al. 2020).

\section{Stable Isotope Analysis}

Bone samples that provided enough collagen for both ${ }^{14} \mathrm{C}$ and stable isotope studies, including three from Shivta, three from Sa'adon and one from Be'er Sheva Zoological Garden (referred to as "Zoological Garden" later in this paper), their carbon and nitrogen stable isotopes are measured with an EA-IRMS system, composed of an elemental analyzer (EA, "vario ISOTOPE SELECT" by Elementar) coupled to an isotope ratio mass spectrometer (IRMS, "isoprime presicION" by Elementar). Ratio of carbon to nitrogen element is presented as weight ratio $\mathrm{C} / \mathrm{N}$. Carbon isotope ratios are compared with Pee Dee Belemnite (PDB) carbonate standards, presented as $\delta^{13} \mathrm{C}$, and nitrogen isotope ratios are compared to atmosphere nitrogen (air) presented as $\delta^{15} \mathrm{~N}$. 


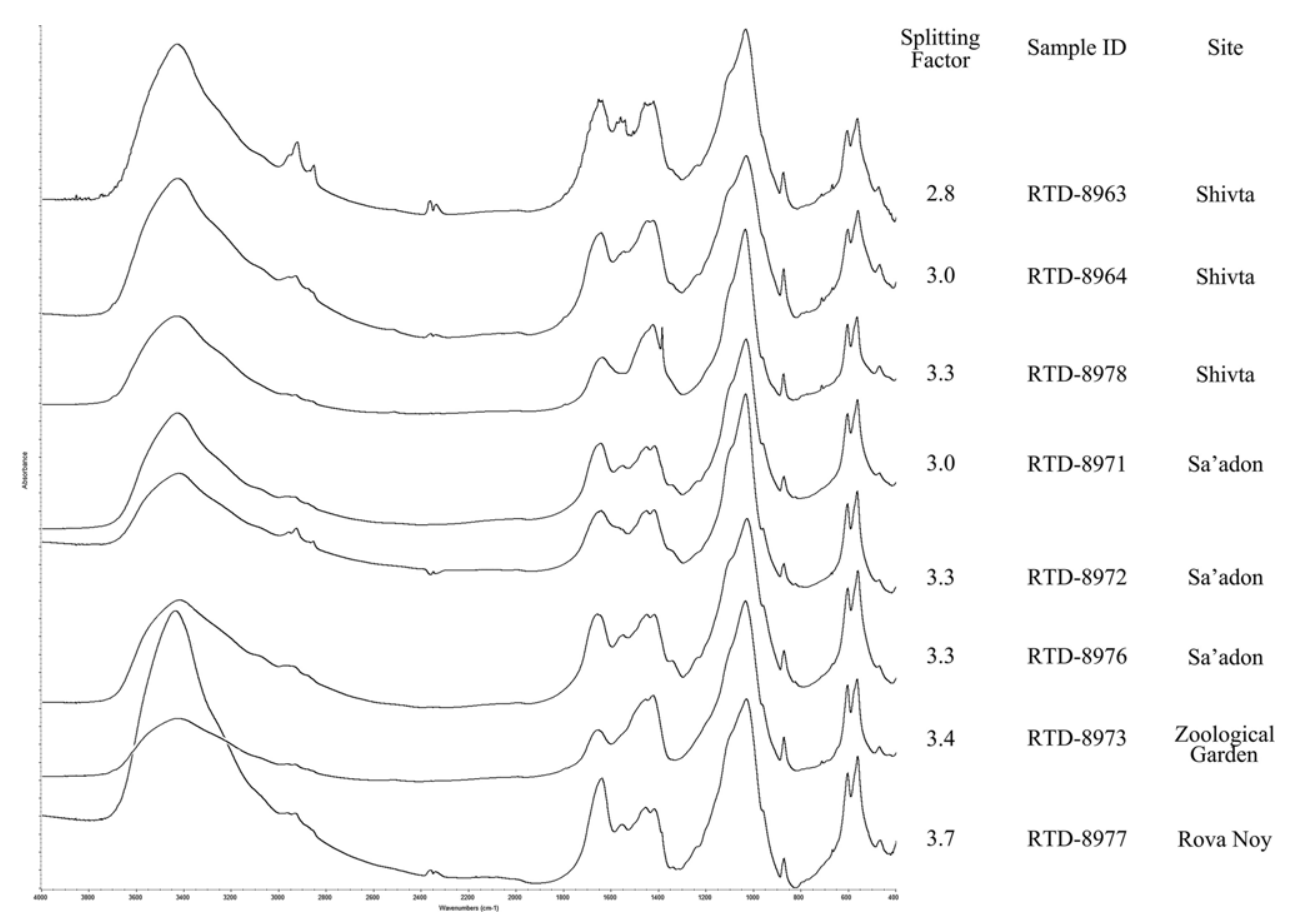

Figure 2 FTIR spectra of pigeon bone samples.

\section{RESULTS}

\section{FTIR}

FTIR spectra of pigeon bone samples before any chemical treatment are show in Figure 2. The eight spectra in Figure 2 are very similar, showing the same peaks for bone minerals as well as collagen, with only a little difference in the ratios of each individual peaks. The peaks at 2920 $2850 \mathrm{~cm}^{-1}$ are the $-\mathrm{CH}_{2}$ and $-\mathrm{CH}_{3}$ groups, indicating the presence of organic material. The peaks between $1670-1550 \mathrm{~cm}^{-1}$ represent Amide I and Amide II of collagen. The two peaks at $1450-1420 \mathrm{~cm}^{-1}$, together with small peaks at 875 and $712 \mathrm{~cm}^{-1}$, represent the carbonate groups. The sharp peak at $1384 \mathrm{~cm}^{-1}$ in the spectrum of the sample from Shivta (RTD8978), represents nitrates; they are soluble in water and can be washed away in later chemical treatments. The major peak at $1035 \mathrm{~cm}^{-1}$, and doublet at 604 and $565 \mathrm{~cm}^{-1}$ are characteristic peaks of apatite, the major mineral composition of bone. The splitting factors are calculated with the sum of the heights of the 604 and $565 \mathrm{~cm}^{-1}$ peaks, divided by the height of the valley between them.

The collagen recovered from collagen extraction procedure was also tested with FTIR spectroscopy and showed similar spectrum. Eight spectra of collagen from four sites, together with a standard spectrum of pure collagen from the Kimmel library, are plotted in Figure 3.

Despite some minor differences in the relative heights of each individual peaks, the eight spectra of collagen samples are similar to each other, and all are similar to the standard. The peaks at $2920-2850 \mathrm{~cm}^{-1}$ are the $-\mathrm{CH}_{2}$ and $-\mathrm{CH}_{3}$ groups, indicating the presence of 


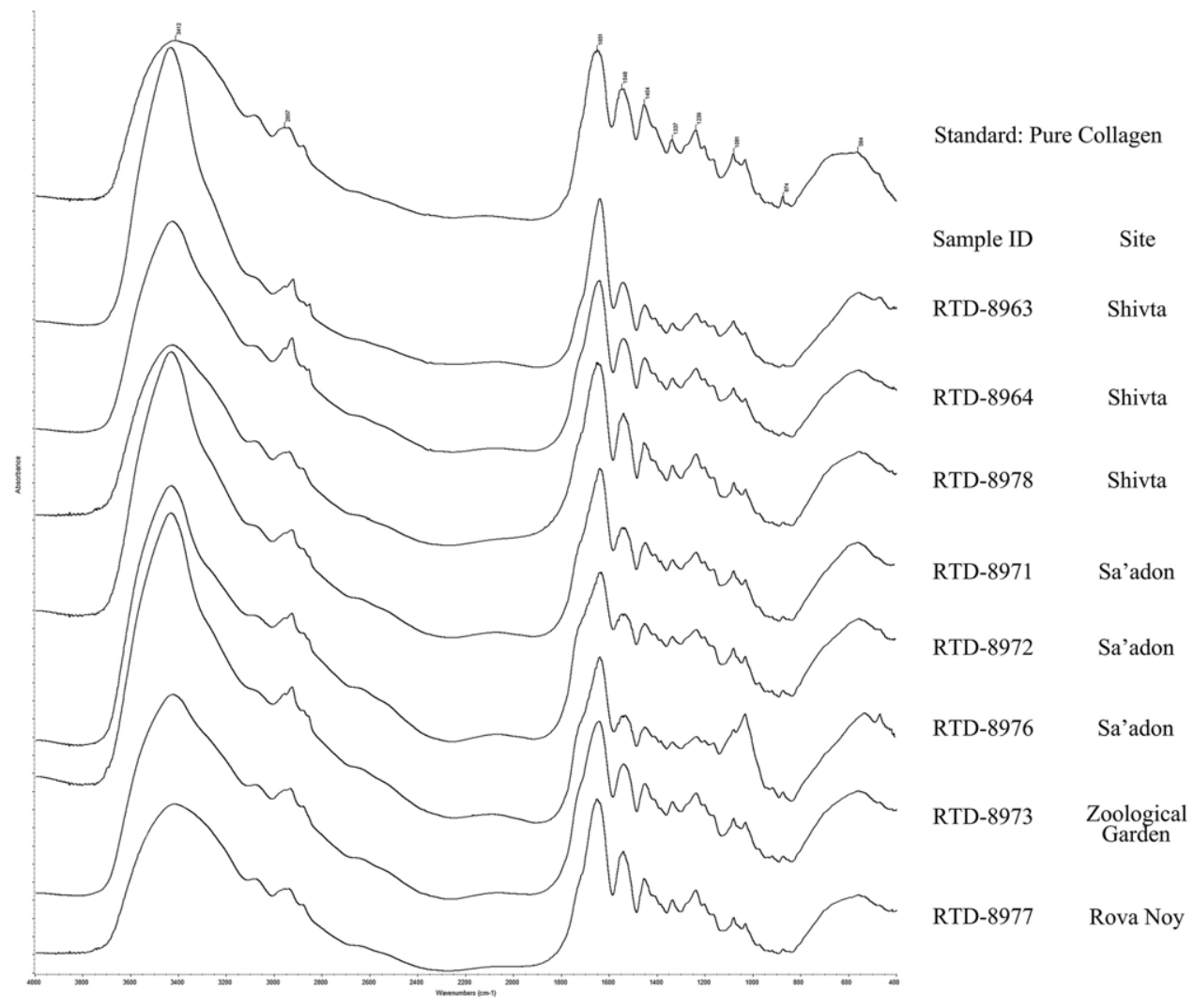

Figure 3 FTIR spectra of collagen extracted from pigeon bone samples, compared with standard spectrum of pure collagen.

organic material. The peaks at around 1650, 1550 and $1450 \mathrm{~cm}^{-1}$ represent Amide I, Amide II, and proline of collagen, respectively.

Compared with the spectra of untreated samples in Figure 2, the carbonate peaks at 1450 1420, 875, and $712 \mathrm{~cm}^{-1}$, the nitrate peak at $1384 \mathrm{~cm}^{-1}$, as well as the apatite peaks at 1035,604 and $565 \mathrm{~cm}^{-1}$ are absent from this group of spectra, indicating successful removal of these inorganic minerals.

\section{Splitting Factor and Collagen Content}

As the splitting factor, which is an indicator for the crystallinity of the apatite mineral, can be affected by the degree of grinding during sample preparation for Infrared spectroscopy with $\mathrm{KBr}$ (Asscher et al. 2011), a grinding curve is more informative on the preservation of the bones. Figure 4 shows the grinding curves of the pigeon bone samples plotted together with modern bird (chicken, Gallus Gallus domesticus) bone sample. Their curves are fitted with linear regression and splitting factors are compared at the same full width at half maximum (FWHM, $140 \mathrm{~cm}^{-1}$ in Figure 4) of the $1035 \mathrm{~cm}^{-1}$ peak.

It is shown in Figure 4 that, with more intensive grinding, the FWHM of the $1035 \mathrm{~cm}^{-1}$ peak decrease, while the splitting factors increase, showing a nearly linear relationship. By 


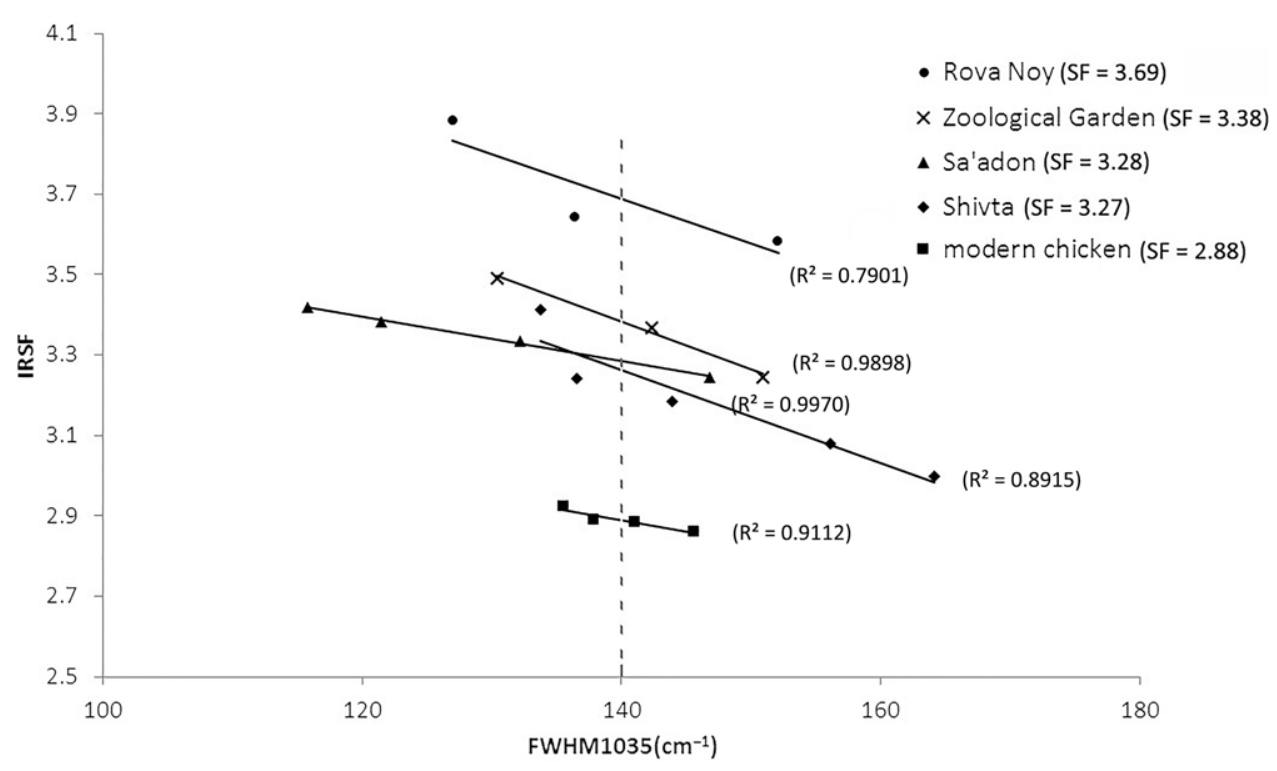

Figure 4 Grinding curves of pigeon bone samples, modern bird (chicken) bone. IRSF of each bone at FWHM1035 $=140 \mathrm{~cm}^{-1}$ are interpolated from linear regression and shown in parentheses in the legend.

comparing at the same FWHM $=140 \mathrm{~cm}^{-1}$, the modern chicken bone has the lowest in splitting factor, and the archaeological samples have higher splitting factor, indicating different degree of diagenesis, this will possibly have influence on the percentage of collagen preserved.

Apart from the splitting factor, the full width at 85\% height of 604 peak (FW85\%) of FTIR spectrum has proved to be indicative of the size of the apatite crystals, which is in turn an indication of preservation (Dal Sasso et al. 2018). In Figure 5, the Infrared splitting factors of pigeon bones from all the pigeon towers, and the modern chicken bone are plotted against their FW85\%. Also plotted in Figure 5 is a fitted curve of fresh bones and archaeology bones from both Israel and Sudan, based on original data taken from Dal Sasso et al. (2018).

As shown in Figure 5, the archaeological pigeon bone samples from pigeon towers in this study are in the range of fresh bone samples, comparing both IRSF and FW $85 \%$, and are very close to the fresh chicken bone sample. Their IRSFs are lower and FW85\% are wider compared to archaeological bones from Sudan and Israel, which are not as well preserved as the pigeon bones in this study.

The collagen extraction and further graphitization procedures also suggest the preservation of the pigeon bone samples. The percentage of collagen extracted from bones after the full pretreatment procedure, and the carbon percentage of the extracted collagen of the pigeon bone samples are plotted against their splitting factors (normalized at FWHM $1035=140 \mathrm{~cm}^{-1}$ ) in Figure 6. Also shown in Figure 6 are the expected range of splitting factors of modern bones (2.5-2.9), the expected ranges of collagen percentage of modern bones (18-20\%) and expected range of carbon percentage of fresh collagen (40-50\%).

The percentages of collagen of pigeon bone samples in this study range between $5.7 \%$ and $11 \%$, closer to the $20 \%$ of fresh bones, compared to most other archaeological bones, and the carbon 


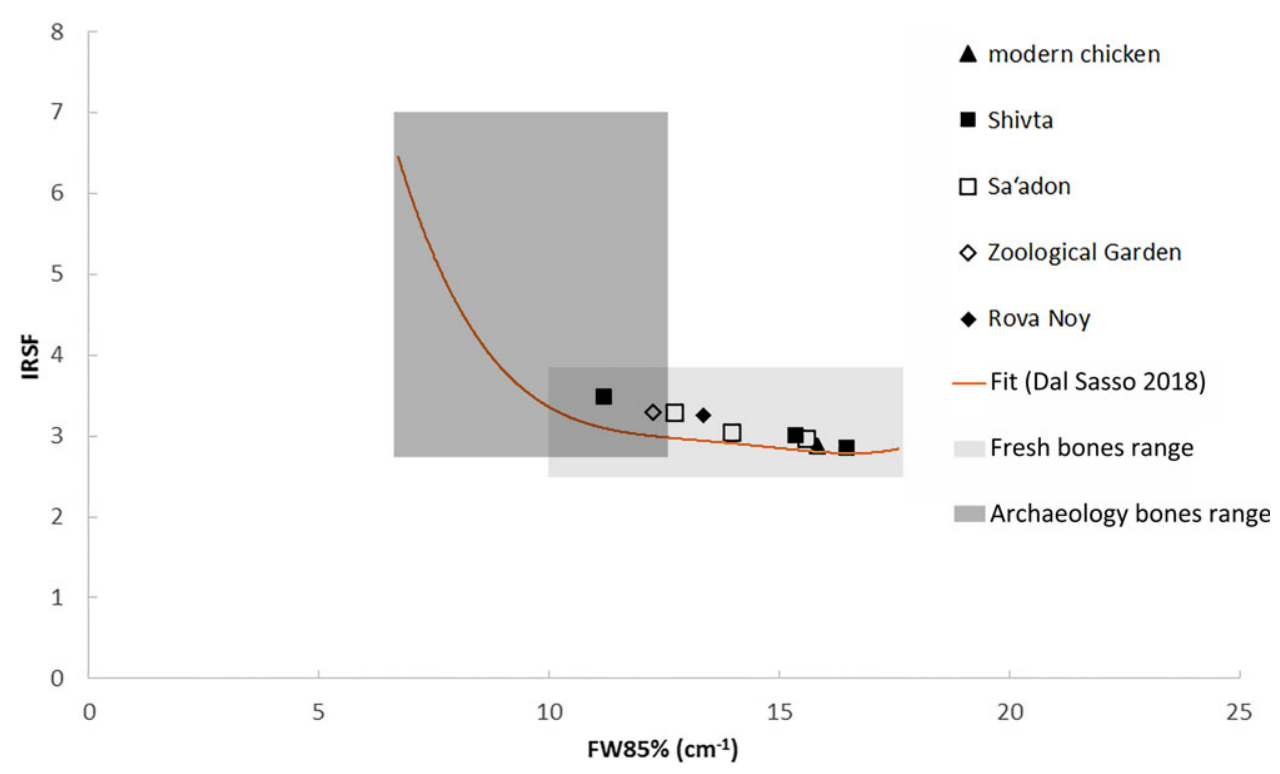

Figure 5 Splitting factors of archaeological pigeon bone samples, fresh chicken bone sample with regard to their FW85\% of 604 peak, compared with fresh bones, archaeological bones from Israel and Sudan in Dal Sasso et al. (2018).

contents of the collagen are around $37-47 \%$, as expected for standard collagen. It is also suggested in Figure 6 that, with the increase of the splitting factor, less collagen is extracted from the bone sample.

Peak intensity ratios of Amide peak $\left(1640 \mathrm{~cm}^{-1}\right)$ to phosphate peak $\left(1035 \mathrm{~cm}^{-1}\right)$ have been calculated from FTIR spectra for each bone sample, and organic contents have been estimated according to the following:

Weight $\%$ organic $=11.06 \ln (\mathrm{Am} / \mathrm{P})+32.43($ Trueman et al. 2004)

The relationship between percentage of collagen extracted from full procedure for ${ }^{14} \mathrm{C}$ dating, and the percentage of organic materials are compared in Supplementary Material 1, and no clear correlation have been observed for the pigeon samples in this study.

Despite the small variations among individual bone samples, all the eight pigeon bones provide enough collagen for generating more than $1 \mathrm{mg}$ of graphite for ${ }^{14} \mathrm{C}$ dating, and except for one sample from Rova Noy (RTD-8977, a fragment of pigeon tibiobarsus bone of ca. $2.0 \mathrm{~cm}$ long and $60 \mathrm{mg}$ before treatment), all the other seven samples provide extra collagen for stable isotope analysis.

\section{Stable Isotopes}

Most pigeon bone samples (seven out of eight) provide enough collagen for both ${ }^{14} \mathrm{C}$ and stable isotope analysis. Carbon and nitrogen isotope ratios of the collagen extracted from these seven samples are listed in Table 2 and plotted in Figure 7. 


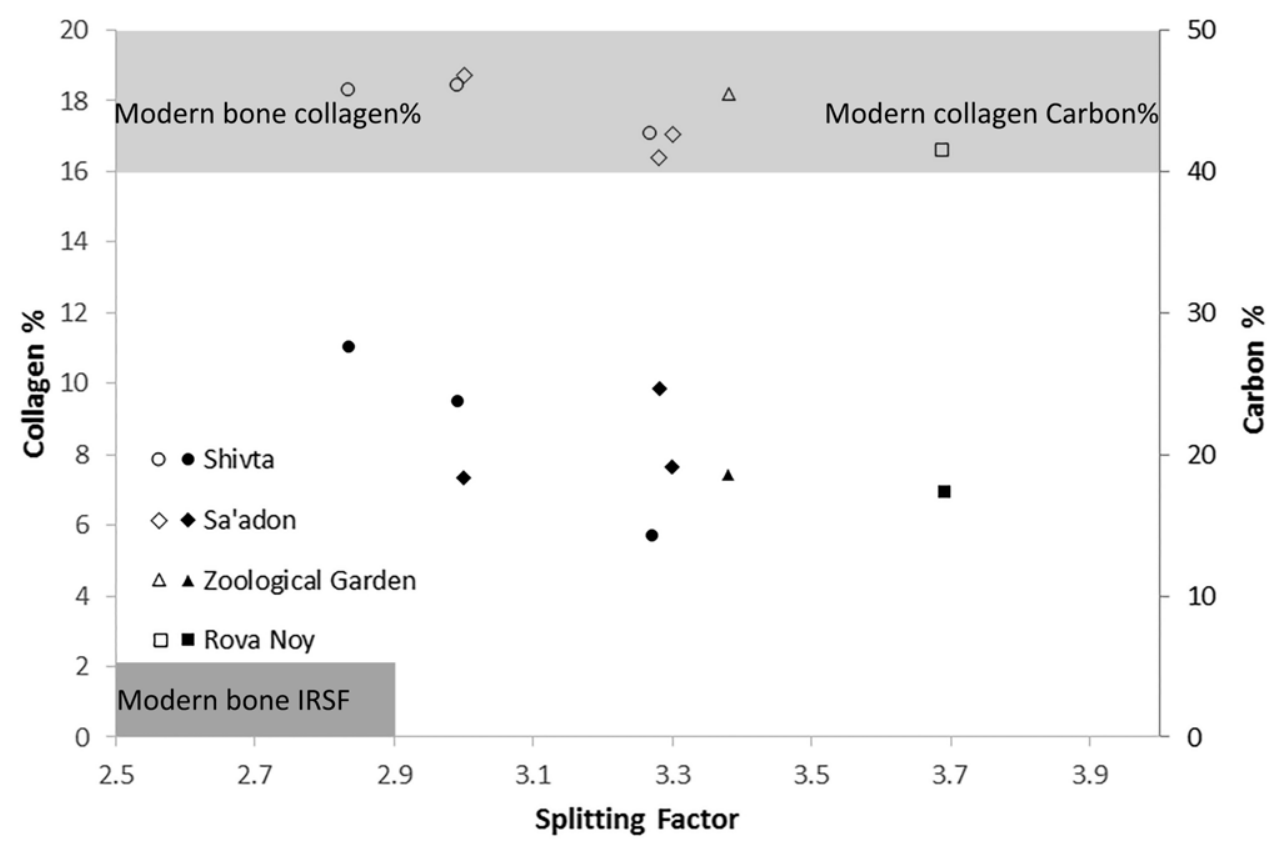

Figure 6 Collagen percentage (closed symbols, left $y$ axis) of each pigeon bone sample from different sites, and carbon percentage of the collagen (open symbols, right $y$-axis), plotted against their splitting factors at FWHM $1035=140 \mathrm{~cm}^{-1}$ $(x$-axis). The ranges of splitting factor (2.5-2.9), collagen percentage (16-20\%), and carbon percentage (40-50\%) of fresh bones are also shown in the plot with gray shades.

The carbon stable isotope of all pigeon samples falls between $-20 \%$ and $-17 \%$, within the range of terrestrial birds between $-22.0 \%$ and $-11.9 \%$ suggested by Schoeninger and DeNiro (1984). Except for one sample from Shivta (RTD-8978) showing nitrogen stable isotope ration of $13.45 \%$, which probably suggests an arid environment in the Negev (Heaton et al. 1986; Pate 1994), all other samples have nitrogen isotope ratios between $1.9 \%$ and $10.0 \%$, the range suggested for terrestrial birds by Schoeninger and DeNiro (1984).

\section{Radiocarbon Dating}

From all the four archaeological sites, a total of five pigeon towers have pigeon bones dated in this study, Shivta having both Building 2 and Building 6 dated.

Eight ${ }^{14} \mathrm{C}$ dates from eight individual bones have been obtained. Table 2 lists the archaeological context, zoological identification, collagen percentage (collagen $\%)$, carbon percentage $(\mathrm{C} \%)$, $\mathrm{C} / \mathrm{N}$ ratio (weight/weight), stable isotope ratio, and ${ }^{14} \mathrm{C}$ date (year $\mathrm{BP}$ ) of each individual dated sample.

For the multiple bone samples from the same structure, i.e., two samples from Shivta Building 6, and three samples of Sa'adon Building B, their ${ }^{14} \mathrm{C}$ ages can be statistically combined, indicating that the pigeon bone samples from the same structure have the same age (Ward and Wilson 1978). Assuming the pigeons in each building died around the same period of time, this is a proof for the reproducibility of this dating method. Each of the eight individual dates, and the two combined dates, have been calibrated and presented in Table 2. We have also tested the combined date for Shivta Building 6 and Sa'adon Building 
Table 2 Archaeological contexts, anatomical part, collagen contents, carbon contents, $\mathrm{C} / \mathrm{N}$ ratios, stable isotope ratios, ${ }^{14} \mathrm{C}$ ages, and calibrated date ranges of the pigeon bones.

\begin{tabular}{|c|c|c|c|c|c|c|c|c|c|c|c|}
\hline \multirow[b]{2}{*}{ Site } & \multirow[b]{2}{*}{ Sample ID } & \multirow[b]{2}{*}{ Arch. context } & \multirow[b]{2}{*}{ Bone type } & \multirow[b]{2}{*}{$\begin{array}{c}\text { Coll. } \\
\%\end{array}$} & \multirow[b]{2}{*}{$\begin{array}{l}\mathrm{C} \\
\%\end{array}$} & \multirow[b]{2}{*}{$\mathrm{C} / \mathrm{N}$} & \multicolumn{2}{|c|}{$\begin{array}{l}\text { Stable } \\
\text { isotope }\end{array}$} & \multirow{2}{*}{$\begin{array}{c}{ }^{14} \mathrm{C} \text { date } \\
\text { (year } \\
\text { BP) }\end{array}$} & \multicolumn{2}{|c|}{ Calibrated date (CE) } \\
\hline & & & & & & & $\begin{array}{c}\delta^{13} \mathrm{C} \\
\% 0\end{array}$ & $\begin{array}{c}\delta^{15} \mathrm{~N} \\
\% 0\end{array}$ & & $\pm 1 \sigma(68.2 \%)$ & $\pm 2 \sigma(95.4 \%)$ \\
\hline \multirow{2}{*}{ Shivta } & RTD-8964 & $\begin{array}{l}\text { Building } 6 \\
\text { L817 B8037 }\end{array}$ & Ulna & 9.50 & 46.0 & 2.79 & -17.52 & 8.16 & $1480 \pm 34$ & $\begin{array}{l}565(52.2 \%) 610 \\
620(16.0 \%) 640\end{array}$ & $545(95.4 \%) 645$ \\
\hline & RTD-8978 & $\begin{array}{l}\text { Building } 2 \\
\text { L207 B2127 }\end{array}$ & Femur & 5.71 & 42.6 & 2.76 & -17.38 & 13.45 & $1437 \pm 24$ & $605(68.3 \%) 645$ & $590(95.4 \%) 655$ \\
\hline \multirow[t]{2}{*}{$\begin{array}{l}\text { Sa'adon } \\
\text { Building B }\end{array}$} & RTD-8976 & L212 B2120 & Femur & 7.34 & 46.8 & 2.75 & -17.29 & 5.05 & $1511 \pm 30$ & $550(68.3 \%) 595$ & $\begin{array}{c}440(3.1 \%) 460 \\
480(3.9 \%) 495 \\
535(83.3 \%) 610 \\
615(5.2 \%) 640\end{array}$ \\
\hline & Combine & Building B & & & & & & & $1534 \pm 16$ & $540(68.3 \%) 570$ & $\begin{array}{c}440(2.0 \%) 450 \\
480(5.4 \%) 495 \\
535(88.1 \%) 595\end{array}$ \\
\hline $\begin{array}{l}\text { Zoological } \\
\text { Garden }\end{array}$ & RTD-8973 & L105 B1027 & Humerus & 7.42 & 45.5 & 2.76 & -18.74 & 3.26 & $1520 \pm 22$ & $545(68.3 \%) 585$ & $\begin{array}{c}440(1.0 \%) 450 \\
480(2.9 \%) 495 \\
535(91.5 \%) 605\end{array}$ \\
\hline Rova Noy & RTD-8977 & L209 B2016 & Tibiobarsus & 6.97 & 41.4 & & & & $1512 \pm 24$ & $550(68.3 \%) 590$ & $\begin{array}{r}480(1.4 \%) 490 \\
535(92.3 \%) 610 \\
625(1.8 \%) 635\end{array}$ \\
\hline
\end{tabular}




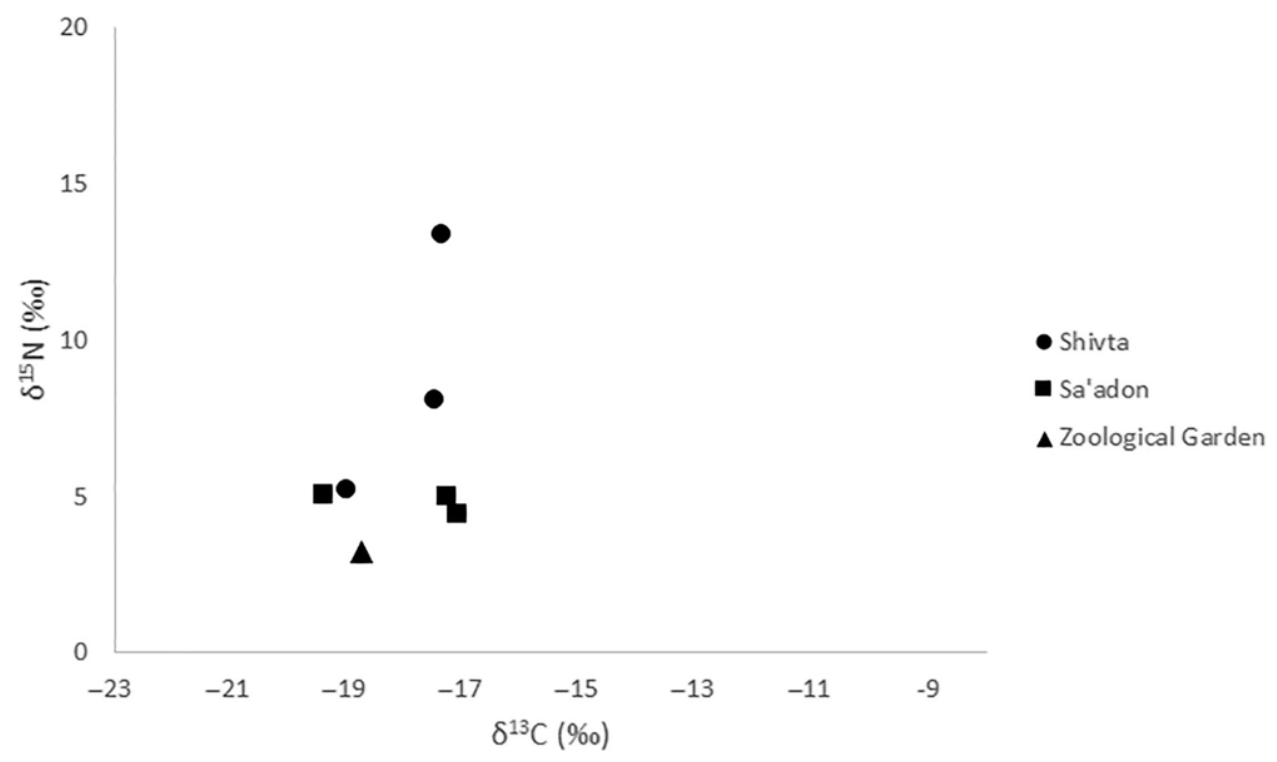

Figure 7 Carbon and Nitrogen stable isotope ratios of collagen extracted from seven pigeon bone samples (from Shivta, Sa'adon and Zoological Garden).

B with the function Combine(), and the results are not significantly different from R_Combine(). A comparison between Combine() and R_Combine is shown in Supplementary Material 3. We have also applied the Difference() function to quantify the difference in age between different pigeon towers, the code and results are shown in Supplementary Material 4.

To test the synchronicity of the abandonment of the five pigeon towers, we applied the $\chi^{2}$ test as suggested in Ward and Wilson (1978), on each bone from each pigeon tower and tested at the degree of freedom $d f=4$. By randomly selecting one date from the pigeon towers that had more than one pigeon bone dated (Shivta Building 6 and Sa'adon Building B) and running multiply $\chi^{2}$ tests with different combinations. The combinations of selected date for test and results are shown in Table 3.

It is suggested by Table 3 that, the $\chi^{2}$ test cannot be passed by all the combinations, therefore the possibility that all the pigeon towers were abandoned simultaneously is low. Furthermore, we applied the Order() function in $\mathrm{OxCal}$, to determine the relative chronology of the pigeon towers as well as the urban decline of Elusa, and the results are shown in Table 4. The latest garbage outside Elusa (RTD-9091, Bar-Oz et al. 2019) was taken as the decline of the urban management of Elusa, and for the pigeon towers with more than one bones dated, i.e. Shivta Building 6 and Sa'adon Building B, the combined date was applied in the Order() function.

From the last row of Table 4, the probability that the urban decline of Elusa dated earlier than the abandonment of pigeon towers at Shivta is more than $95 \%(99.48 \%$ earlier than Shivta Building 2, and 95.04\% earlier than Shivta Building 6), and the probability of Elusa decline dated earlier than pigeon towers in zoological Garden and Rova Noy is $74.43 \%$ and 79.82 , respectively. The pigeon tower in Sa'adon might have been abandoned around the same time or slightly later than the urban decline of Elusa, with a probability of $65.3 \%$ to be later. Among the pigeon towers, the probability of Shivta Building 2 abandoned later than 
Table 3 Results of $\chi^{2}$ tests for the five pigeon towers.

\begin{tabular}{|c|c|c|c|}
\hline Date for Shivta Building 6 & $\begin{array}{l}\text { Date for Sa'adon } \\
\text { Building B }\end{array}$ & $\begin{array}{c}\mathrm{T} \text { value } \\
(d f=4,5 \%, 9.5)\end{array}$ & Pass/fail \\
\hline$\overline{\text { RTD-8963 }}$ & RTD-8971 & 9.548 & Fail \\
\hline RTD-8963 & RTD-8972 & 12.557 & Fail \\
\hline RTD-8963 & RTD-8976 & 8.2 & Pass \\
\hline RTD-8964 & RTD-8971 & 9.4 & Pass \\
\hline RTD-8964 & RTD-8972 & 12.376 & Fail \\
\hline RTD-8964 & RTD-8976 & 8.1 & Pass \\
\hline R_Combine (RTD 8963-8964) & $\begin{array}{l}\text { R_Combine } \\
\text { (RTD 8971-8972-8976) }\end{array}$ & 12.970 & Fail \\
\hline
\end{tabular}

Table 4 Results of Order() function for the five pigeon towers and garbage outside the city of Elusa.

\begin{tabular}{|c|c|c|c|c|c|c|}
\hline \multicolumn{7}{|c|}{ Probability $t_{1}<t_{2}$} \\
\hline \multirow[b]{2}{*}{$t_{1}$} & \multicolumn{6}{|c|}{$t_{2}$} \\
\hline & $\begin{array}{c}\text { Shivta } 2 \\
\text { RTD- } \\
8978\end{array}$ & $\begin{array}{l}\text { Combine } \\
\text { Shivta } 6\end{array}$ & $\begin{array}{c}\text { ZG } \\
\text { RTD- } \\
8973\end{array}$ & $\begin{array}{c}\text { RN } \\
\text { RTD- } \\
8977\end{array}$ & $\begin{array}{c}\text { Combine } \\
\text { Sa'adon } \\
\text { B }\end{array}$ & $\begin{array}{c}\text { Elusa } \\
\text { RTD- } \\
9091\end{array}$ \\
\hline $\begin{array}{l}\text { Shivta } 2 \text { RTD- } \\
8978\end{array}$ & - & 0.2087 & 0.015 & 0.03208 & 0.002033 & 0.005225 \\
\hline Combine Shivta 6 & 0.7913 & - & 0.12846 & 0.1875 & 0.03936 & 0.0496 \\
\hline ZG RTD-8973 & 0.985 & 0.8715 & - & 0.584 & 0.3292 & 0.25572 \\
\hline RN RTD-8977 & 0.9679 & 0.8125 & 0.4161 & - & 0.24742 & 0.20182 \\
\hline $\begin{array}{l}\text { Combine } \\
\text { Sa'adon B }\end{array}$ & 0.998 & 0.9606 & 0.6708 & 0.7526 & - & 0.347 \\
\hline Elusa RTD-9091 & 0.9948 & 0.9504 & 0.7443 & 0.7982 & 0.653 & - \\
\hline
\end{tabular}

Zoological Garden (98.50\%), Rova Noy (96.79\%), and Sa'adon Building B $(99.80 \%)$ are all higher than $90 \%$, while the probability of Shivta Building 2 abandoned later than Shivta Building 6 is $79.13 \%$. The probability of Shivta Building 6 abandoned later than Zoological Garden (87.15\%), Rova Noy (81.25\%), and Sa'adon Building B (96.06\%) are all higher than $80 \%$. And the abandonment of Zoological Garden, Rova Noy and Sa'adon Building B might have been at the same time, according to Table 4.

We do not exclude the possibilities that pigeon towers from different site could have been abandoned at the same time, e.g., Sa'adon Building B and the two pigeon towers around Be'er Sheva (Zoological Garden and Rova Noy), or Be'er Sheva and Shivta Building 6, however, we would like to suggest, the most possible scenario for the abandonment of pigeon towers in the Negev is a gradual process following the urban decline of Elusa. The pigeon tower in Sa'adon was the first to be abandoned, at the same time or right after the decline of Elusa, at mid-6th century CE. Then followed the pigeon towers at the Zoological Garden and Rova Noy, towards the end of the 6th century CE. The two pigeon towers at Shivta were the last to be abandoned, at the end of the 6th century and beginning of 7 th 


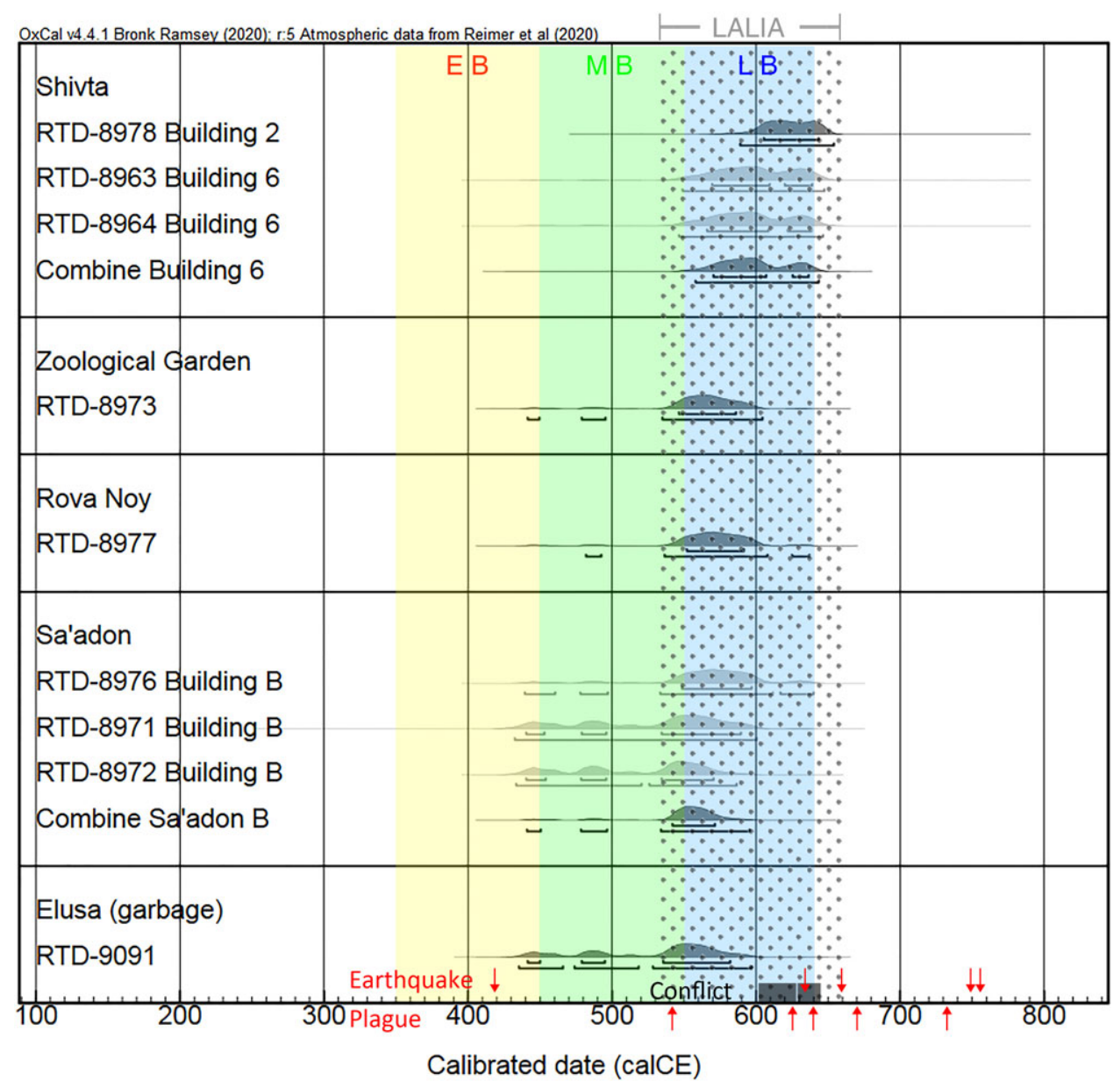

Figure 8 Probability distribution calibrated dates. Dates from the same building are combined, dates before combine are shown with lighter colors than the combined dates. Different time periods are shaded with different colors in the plot, with early Byzantine (EB, 350-450 CE) in yellow, middle Byzantine (MB, 450-550 CE) in green and late Byzantine (LB, 550-640 CE) in blue, and the LALIA (536-ca. $660 \mathrm{CE}$ ) is indicated with dots. Years of conflicts with Sasanian Empire (602-628) and Arabs (629-644) are marked with bars, and red arrows show years of earthquakes and waves of Justinianic Plague that hit the Southern Levant.

century CE, and these two pigeon towers could have been abandoned at the same time, but the probability of Building 2 abandoned after Building 6 is $79 \%$.

In previous work of ${ }^{14} \mathrm{C}$ dating of the Byzantine city of Elusa, which is also located in the Negev, the decline of the urban management of the city was determined by the decrease in garbage dumping outside the city and dated to no later than $550 \mathrm{CE}$ (Bar-Oz et al. 2019). The results from pigeon towers in this study, together with the youngest date from Elusa garbage dump (RTD-9091; Bar-Oz et al. 2019) are plotted in Figure 8. In cases of more than one date from the same pigeon tower (two dates from Shivta Builing 6 and three dates from Sa'adon Building B), the original dates before combine are shown in light gray, and the combined dates are shown in dark gray, the same color as the other pigeon towers 
that produced single date. Also shown with color are periods of archaeological culture according to Bar-Oz et al. (2019): Early Byzantine (350-450 CE) in yellow, Middle Byzantine (450-550 CE) in green, and Late Byzantine (550-640 CE) in Blue, as well as the Late Antique Little Ice Age (LALIA: 536-ca. 660 CE; Büntgen et al. 2016) with gray dots. Black bars show violent conflicts between the Byzantine Empire and the Sasanian Empire (602-628 CE) and the Arabic invasions (629-644 CE). Earthquakes that hit the Southern Levant from this period $(418,634,659,749$, and 756 CE; Zohar et al. 2016) and waves of Justinianic Plague that hit the Southern Levant (541-544, 626-628, 639, 669-673, and 732735 CE; Mordechai et al. 2019) are also marked with red arrows in the plot.

The plot shows that the pigeon towers in Sa'adon, Be'er Sheva Zoological Garden and Rova Noy, ended between 550-600 CE, while the Building 2 at Shivta was the latest to end, between 600-650 CE. Although we cannot exclude the possibilities of Shivta Building 6 ending synchronously with the first group (Sa'adon, Zoological Garden and Rova Noy), or the younger one (Shivta Building 2), judging by the highest probability, it seems to end between these two groups, with $55.8 \%$ probability of calibrated range between $570-605$ (Table 2).

Despite the fact that RTD-9091 from garbage outside Elusa has some probability distribution between 550 and $600 \mathrm{CE}$, the other seven dates from the same site all point to the conclusion that the major urban decline of the city of Elusa happened before $550 \mathrm{CE}$ (Bar-Oz et al. 2019). Pigeon bones dated in this study indicate that most of the pigeon towers stopped functioning within 50 years after the decline of the city of Elusa, only one from Shivta (Building 2) lasted longer, but still no more than 100 years after Elusa's decline.

\section{DISCUSSION}

\section{Preservation of Bones and Eligibility for Radiocarbon Dating}

The degree of crystallinity of carbonate hydroxyapatite characterized by the Infrared splitting factor and the grinding curve, the high collagen percentage, and the typical percentage carbon of the collagen, all show very well-preserved bone collagen in the eight pigeon bone samples from all five pigeon towers in this study. This on one hand provides enough collagen for radiocarbon dating from ca. $100 \mathrm{mg}$ of bones; on the other hand, it further testifies little evidence for post-depositional bone degradation and diagenesis. The excellent preservation of these small bones might be due to a combination of low humidity and rain in the region. This result ensures that the collagen of the pigeon bones is authentic, and the obtained dates can provide reliable results for the last occupational phase of the pigeon towers.

Previous published dates of pigeon towers include one dated by a piece of wood from Shivta Building 2 (Hirschfeld and Tepper 2006), and one dated by pigeon dung from Shivta Building 6 (Ramsay et al. 2016). The wood date of 240-380 CE can only offer a terminus post quem for the construction phase of the pigeon tower, due to the old wood effect, and it does not provide the last date of occupation. And the radiocarbon dating of pigeon dung, which in theory should date the last use of the pigeon tower, reached a calibrated date of 435-640 CE in 95.4\% probability range, older than pigeon bones from the same structure, 560-645 CE in 95.4\% probability range. The difference between the two dates could probably result from the clay in the dung samples that is almost impossible to remove from the sample completely and contains older carbon (Dunseth et al. 2019). Bones, on the other hand, lack this component and therefore their dates are more accurate. 
In this study, by extracting collagen from in situ and well-preserved bones, and examining purity of collagen with various characterization methods, we exclude any possible contaminants, to ensure the radiocarbon dates can represent the living time of the pigeons, and eventually date the last occupation of the pigeon towers.

\section{Utilization and Abandonment of Pigeon Towers}

While functioning as supplier for agricultural fertilizers, the pigeon towers were routinely cleaned of pigeon dung by the farmers. As a result, the radiocarbon dates of the pigeon bones found in situ in the dung layer above the floors of pigeon towers indicate the last use of the pigeon towers.

The radiocarbon results show that pigeon towers have most probably stopped their function gradually during the Late Byzantine period (550-640 CE), following the decline of urban management in the city of Elusa (Bar-Oz et al. 2019). The presence of Early Islamic pottery sherds found in the upper debris layers of two of the dovecotes (Shivta Building 2 and Zoological Garden) is the result of stone robbing in the Early Islamic period. All the dated dung and pigeon bones related to the use of the structure are before the Early Islamic period.

Previous studies suggest the constructions of the pigeon towers outside Shivta started in the Roman period, the 2 nd century CE, as part of the extensive agriculture system (Hirschfeld and Tepper 2006; Tepper et al. 2020). In this study, by applying radiocarbon dating on pigeon bones, we acquired higher resolution than previously published dating on pigeon towers using pigeon dung and wood beams and suggest the end of using pigeons for agricultural purposes before the end of the Byzantine period. Although some agricultural activities might continue in the Early Islamic period and in some other places in the Negev Highlands even later until the 11th century CE (Avni et al. 2013; Tepper et al. 2020), the practice of rearing pigeons and collecting pigeon manure for agriculture fertilizers is no longer observed by the later residents in the Negev since the Early Islamic period.

\section{Correlation with Historical Background}

The decline of this type of agricultural behavior began in the mid-6th century, with the end of Sa'adon being an early sign. Looking into the historical background, long-term societal changes at the Negev could have been triggered by broader worldwide events. Parallel to the urban collapse of Elusa, there is also evidence of a significant global climatic environmental deterioration primarily in Europe (the LALIA of 536-ca. $660 \mathrm{CE}$ ) that might have not necessarily affected the climate of the Negev, but influenced its commerce (Bar-Oz et al. 2019; McCormick 2001; Fuks et al. 2020), as well as the Justinianic Plague waves that claimed tens of millions of lives around the Mediterranean (541-ca. 750 CE; Benovitz 2014).

During this period, a few earthquakes are also recorded (Zohar et al. 2016) and violent conflicts could be the cause for the pigeon towers destruction and abandonment as well (Hirschfeld and Tepper 2006). We exclude these possibilities as the historical dates of the earthquakes that hit the Southern Levant (418 CE and $634 \mathrm{CE}$; see Figure 8) are before or after the absolute dates of the pigeon towers abandonment and therefore they are not the cause for it. The Sasanian (602$628 \mathrm{CE}$ ) and Arabic invasions (629-644 CE) could explain the abandonment of the Shivta Building 2, last dated pigeon tower in the region, but not for the general process of pigeon tower abandonment. 
A recent study on the Justinianic Plague by Mordechai et al. (2019) suggests that "plague did not play a significant role in the transformation of the Mediterranean world or Europe." Following this scenario, we anticipate that in the Negev villages and rural settlements, where the population was less dense, the impact of Justinianic Plague was minimal. Moreover, according to Avni (2014), "a reduction in public construction was noted in 540's and attributed to the effects of plague and famine, but, in the second half of the 6th century and the first half of the 7th century building resume." Furthermore, we have figured out that the abandonment of the pigeon towers was not abrupt, but was more in a sequential order, starting from the mid-6th century CE at Sa'adon, until the beginning of the 7th century CE at Shivta Building 2, lasting ca. 100 years. Among of the 18 waves of Justinianic Plague (Mordechai et al. 2019), only 5 are reported to reach the southern Levant (Mordechai et al. 2019) and their outbreak timing is in $541 \mathrm{CE}$ for the first and $626 \mathrm{CE}$ for the second (Figure 8). These points of time are either before or after the dates of pigeon towers' abandonment and they do not support such a sequence of abandonment. We believe that these results cannot support the Justinianic Plague as the main cause for the agriculture abatement in the Negev.

To link the climate change directly with the decline of agriculture in the Negev, more local climate records need to be referred to. Based on isotopic analysis of sheep and goat teeth from (early and middle 350-550 CE) Byzantine and early Islamic (starting $640 \mathrm{CE}$ ) specimens from the same excavated sites in the Negev, Vaiglova et al. (2020) found that a similar climate persisted during the studied periods. Unfortunately, none of the studied material included specimens from the late Byzantine $(550-640 \mathrm{CE})$ period, which significantly overlaps with the same time period as LALIA. The late Byzantine climate conditions in the Negev, after Vaiglova et al (2020), remain to be an enigma. One of the most well documented climatic records in the Southern Levant is the Soreq Cave speleothem. Unfortunately, the resolution of this record during this period is not high enough and contains only on one data point between 550-640 CE (Orland et al. 2009). This is interpreted as an indication of low precipitation rate and therefore very slow stalagmite formation, taking into account that the developed layer is thin. Although Soreq Cave is located above the $600 \mathrm{~mm}$ isohyet of today (Dody and Ziv 2013), and receives much higher annual precipitation than the Negev, it still represents a regional climate record. In this study, all the five pigeon towers terminated their function during 550-640 CE. This time interval is synchronized with LALIA, and therefore corresponds the climatic event with the societal and agricultural change in the Negev arid landscape. Even if the local climate and population was not affected by the LALIA or the Justinianic Plague in the same way as in Europe, the population and economic decline in Europe could affect the viticulture in the Negev via a decreased demand for wine export (Fuks et al. 2020; Lanos et al. 2020).

\section{CONCLUSION}

We uncovered pigeon bone remains in situ in pigeon towers from four Byzantine sites in the Negev desert of Israel, where other evidence of agriculture have also been found. Various characterization methods have proved the pigeon bones are in very good condition of preservation and suitable for high precision absolute ${ }^{14} \mathrm{C}$ dating and stable isotope analysis. A total of eight ${ }^{14} \mathrm{C}$ dates show these pigeon towers stopped being in function between 550 and $640 \mathrm{CE}$, during the Late Byzantine period in the Negev. This indicates that the prominent and gradual decrease of the extensive agricultural practice in the Negev around the Byzantine sites was part of the decline of the Byzantine era in the fringe of the Empire. Our studies show that the abandonment of the pigeon towers was most probably drive by 
the climate change in the 6th-7th centuries CE, and the Justinianic Plague, earthquakes or violent conflicts are less conceivable.

\section{ACKNOWLEDGMENTS}

This study was supported by the European Research Council (ERC) under the European Union's Horizon 2020 research and innovation program (grant agreement No. 648427) and the National Geographic Society (grant no. 3857/10). This study was conducted under the excavation licenses of the Israel Antiquities Authority (G-30/2011; G-31/2011). We thank Davida Eisenberg-Degen (Rova Noy) and Federico Kobrin (Be'er Sheva Zoological Garden) from the Israel Antiquities Authority for providing us with pigeon bones for radiocarbon study from their excavations (IAA licenses: A-7658; A-7494). The Radiocarbon research was supported by the Exilarch Foundation for the Dangoor Research Accelerator Mass Spectrometer (D-REAMS) Laboratory. E.B. is the incumbent of the Dangoor Professorial Chair of Archaeological Sciences at the Weizmann Institute of Science.

\section{SUPPLEMENTARY MATERIAL}

To view supplementary material for this article, please visit https://doi.org/10.1017/RDC. 2021.85.

\section{REFERENCES}

Asscher Y, Weiner S, Boaretto E. 2011. Variations in atomic disorder in biogenic carbonate hydroxyapatite using the infrared spectrum grinding curve method. Advanced Functional Materials 21(17):3308-3313

Avni G. 2014. The Byzantine-Islamic transition in Palestine: an archaeological approach. Oxford University Press.

Avni G, Porat N, Avni Y. 2013. Byzantine-Early Islamic agricultural systems in the Negev Highlands: Stages of development as interpreted through OSL dating. Journal of Field Archaeology 38(4):332-346.

Bar-Oz G, Weissbrod L, Erickson-Gini T, Tepper Y, Malkinson D, Benzaquen $\mathrm{M}$, Langgut $\mathrm{D}$, Dunseth ZC, Butler DH, Shahack-Gross R, Roskin J, Fuks D, Weiss E, Marom N, Ktalav I, Blevis R, Zohar I, Farhi Y, Filatova A, GorinRosen Y, Yan X, Boaretto E. 2019. Ancient trash mounds unravel urban collapse a century before the end of Byzantine hegemony in the southern Levant. Proceedings of the National Academy of Sciences 116(17):8239-8248.

Benovitz N. 2014. The Justinianic plague: evidence from the dated Greek epitaphs of Byzantine Palestine and Arabia. Journal of Roman Archaeology 27:487-498.

Boaretto E, Wu X, Yuan J, Bar-Yosef O, Chu V, Pan Y, Liu K, Cohen D, Jiao T, Li S, Gu H. 2009. Radiocarbon dating of charcoal and bone collagen associated with early pottery at Yuchanyan Cave, Hunan Province, China.
Proceedings of the National Academy of Sciences 106(24):9595-9600.

Brock F, Higham T, Ditchfield P, Ramsey CB. 2010. Current pretreatment methods for AMS radiocarbon dating at the Oxford Radiocarbon Accelerator Unit (ORAU). Radiocarbon 52(1): 103-112.

Brock F, Bronk Ramsey C, Higham T. 2007. Quality assurance of ultrafiltered bone dating. Radiocarbon 49(2): 187-192.

Bronk Ramsey C, Lee S. 2013. Recent and planned developments of the program OxCal. Radiocarbon 55(2):720-730

Büntgen U, Myglan VS, Ljungqvist FC, McCormick M, Di Cosmo N, Sigl M, Jungclaus J, Wagner S, Krusic PJ, Esper J, Kaplan JO. 2016. Cooling and societal change during the Late Antique Little Ice Age from 536 to around 660 AD. Nature Geoscience 9(3):231-236.

Columella LJM. 1941. On Agriculture 3 volumes Harvard University Press (H.B. Ash, E.S. Forster, Edward Heffner, translators).

Dal Sasso G, Asscher Y, Angelini I, Nodari L, Artioli G. 2018. A universal curve of apatite crystallinity for the assessment of bone integrity and preservation. Scientific Reports 8(1):12025.

Dody A, Ziv B. 2013. Factors affecting isotopic composition of the rainwater in the Negev Desert, Israel. Journal of Geophysical Research: Atmospheres 118(15):8274-8284.

Dunseth ZC, Fuks D, Langgut D, Weiss E, Melamed Y, Butler DH, Yan X, Boaretto E, Tepper Y, Bar- 
Oz G, Shahack-Gross R. 2019. Archaeobotanical proxies and archaeological interpretation: A comparative study of phytoliths, pollen and seeds in dung pellets and refuse deposits at Early Islamic Shivta, Negev, Israel. Quaternary Science Reviews 211:166-185.

Eisenberg-Degen D. 2017. Be'er Sheva (South). Preliminary report. Excavation and Survey in Israel. 129 (English-Hebrew, 14.3.2017). http:// www.hadashot-esi.org.i1/Report_Detail_Eng.aspx? $\mathrm{id}=25190 \&$ mag_id $=125$.

Fried T, Weissbrod L, Tepper Y, Bar-Oz G. 2018. A glimpse of an ancient agricultural ecosystem based on remains of micromammals in the Byzantine Negev Desert. Royal Society Open Science 5(1):171528.

Fuks D, Bar-Oz G, Tepper Y, Erickson-Gini T, Langgut D Weissbrod L, Weiss E. 2020. The rise and fall of viticulture in the Late Antique Negev Highlands reconstructed from archaeobotanical and ceramic data. Proceedings of the National Academy of Science USA 117(33):19780-19791.

Gil'ad Y, Fabian P. 2008. 7,000 Years of settlement: the archaeological remains in Be'er Sheva' from the sixth millennium BCE until the end of the first millennium CE. In: Gradus Y, MeirGlitzenstein E, editors. Be'er Sheva': Metropolin Be-Hithavut [An Evovlving Metropolis]: Selected Articles. Be'er Sheva'. p. 303-331. In Hebrew.

Goldenberg L, Regev L, Mintz E, Boaretto E. 2017. Dating reassembled collagen from fossil bones. Radiocarbon 59(5):1487-1496.

Haiman M, Argaman E, Stavi I. 2020. Ancient runoff harvesting agriculture in the arid Beer Sheva Valley, Israel: an interdisciplinary study. The Holocene doi: 10.1177/0959683620913917.

Harper K. 2017. The fate of Rome: climate, disease, and the end of an empire. Princeton (NJ): Princeton University Press.

Heaton TH, Vogel JC, vo La Chevallerie G, Collett G. 1986. Climatic influence on the isotopic composition of bone nitrogen. Nature 322(6082): 822-823.

Hirschfeld Y. 2006. The crisis of the sixth century: climatic change, natural disasters and the plague. Mediterranean Archaeology and Archaeometry 6:19-32.

Hirschfeld Y, Tepper Y. 2006. Columbarium towers and other structures in the environs of Shivta. Tel Aviv 33(1):83-116.

Kobrin F, Tepper Y. 2017. Be'er Sheva', the Zoological Park. Preliminary report. Excavation and Survey in Israel. 129 (English-Hebrew, 3.10.2017). http://www.hadashot-esi.org.il/Report_ Detail_Eng.aspx?id=25300\&mag_id=125.

Lanos S, Bar-Oz G, Gambash G. 2020. Wine from the desert: Late Antique Negev viniculture and the famous Gaza Wine. Near Eastern Archaeology 83:56-64.
Magness J. 2003. The archaeology of the early Islamic settlement in Palestine. Vol. 1. Eisenbrauns.

Marom N, Meiri M, Tepper Y, Erickson-Gini T, Reshef H, Weissbrod L, Bar-Oz G. 2019. Zooarchaeology of the social and economic upheavals in the Late Antique-Early Islamic sequence of the Negev Desert. Scientific Reports 9(1):1-10.

Marom N, Rosen B, Tepper Y, Bar-Oz G. 2018. Pigeons at the edge of the empire: bioarchaeological evidences for extensive management of pigeons in a Byzantine desert settlement in the southern Levant. PloS One 13(3):e0193206.

McCormick M. 2001. Origins of the European economy: communications and commerce AD 300-900. Cambridge University Press.

Mordechai L, Eisenberg M, Newfield TP, Izdebski A, Kay JE, Poinar H. 2019. The Justinianic Plague: an inconsequential pandemic? Proceedings of the National Academy of Sciences 116(51):2554625554.

Orland IJ, Bar-Matthews M, Kita NT, Ayalon A, Matthews A, Valley JW. 2009. Climate deterioration in the Eastern Mediterranean as revealed by ion microprobe analysis of a speleothem that grew from 2.2 to $0.9 \mathrm{ka}$ in Soreq Cave, Israel. Quaternary Research 71(1):27-35.

Pat FD. 1994. Bone chemistry and paleodiet. Journal of Archaeological Method and Theory 1(2):161209.

Pliny the Elder. 1952. Natural history. English translation by Rackham H. Cambridge (MA): Harvard University Press.

Pliny the Elder. 2021. The natural history. Chapter 6. http://data.perseus.org/citations/urn:cts:latinLit: phi0978.phi001.perseus-eng1:17.6.

Ramsay J, Tepper Y, Weinstein-Evron M, Aharonovich S, Liphschitz N, Marom N, BarOz G. 2016. For the birds-an environmental archaeological analysis of Byzantine pigeon towers at Shivta (Negev Desert, Israel). Journal of Archaeological Science: Reports 9:718-727.

Regev L, Steier P, Shachar Y, Mintz E, Wild EM, Kutschera W, Boaretto E. 2017. D-REAMS: a new compact AMS system for radiocarbon measurements at the Weizmann Institute of Science, Rehovot, Israel. Radiocarbon 59(3): 775-784.

Reimer PJ, Austin WEN, Bard E, Bayliss A, Blackwell PG, Ramsey CB, Butzin M, Cheng $\mathrm{H}$, Edwards RL, Friedrich M, Grootes PM, Guilderson TP, Hajdas I, Heaton TJ, Hogg AG, Hughen KA, Kromer B, Manning SW, Muscheler R, Palmer JG, Pearson C, van der Plicht J, Reimer RW, Richards DA, Scott EM, Southon JR, Turney CSM, Wacker L, Adolphi F, Büntgen U, Capano M, Fahrni SM, Fogtmann-Schulz A, Friedrich R, Köhler P, Kudsk P, Miyake F, Olsen J, Reinig F, Sakamoto M, Sookdeo A, Talamo S. 2020. The 
IntCal20 Northern Hemisphere radiocarbon age calibration curve (0-55 cal kBP). Radiocarbon 62(4):725-757. doi: 10.1017/RDC.2020.41.

Schoeninger MJ, DeNiro MJ. 1984. Nitrogen and carbon isotopic composition of bone collagen from marine and terrestrial animals. Geochimica et Cosmochimica Acta 48(4):625639.

Tepper Y. 1986. The rise and fall of dove-raising. In: Kasher A, Oppenheimer A, Rappaport U, editors. Man and land in Eretz-Israel in Antiquity. Jerusalem. p. 170-196. In Hebrew.

Tepper Y. 2007a. In: Arbel B, Terkel J, Menache S, editors. Columbarium, Peristeron, and Dovecote (Shovakh): pigeon raising in Eretz-Israel at the Hellenistic, Roman and Byzantine period. Human beings and other animals in historical perspective. Jerusalem. p. 133-160. In Hebrew.

Tepper Y. 2007b. Soil improvement and agricultural pesticides in antiquity: examples from archaeological research in Israel. In: Conan M, editor. Middle East garden traditions: unity and diversity: Dumbarton Oaks Colloquium on the History of Landscape Architecture XXXI. Washington (DC): Dumbarton Oaks. p. 41-52.

Tepper Y, Erickson-Gini T, Farhi Y, Bar-Oz G. 2018a. Probing the Byzantine/Early Islamic transition in the Negev: the renewed Shivta excavations. 2015-2016. Tel Aviv 45(1):120-152.

Tepper Y, Porat N, Bar-Oz G. 2020. Sustainable farming in the Roman-Byzantine period: dating an advanced agriculture system near the site of Shivta, Negev Desert, Israel. Journal of Arid Environments 177:104134.

Tepper Y, Rosen B, Haber A, Bar-Oz G. 2017. Signs of soil fertigation in the desert: a pigeon tower structure near Byzantine Shivta, Israel. Journal of Arid Environments 145:81-89.

Tepper Y, Weissbrod L, Bar-Oz G. 2015. Behind sealed doors: unravelling abandonment dynamics at the Byzantine site of Shivta in the Negev Desert. Antiquity Project Gallery 348.: http://antiquity.ac.uk/projgall/bar-oz348.
Tepper Y, Weissbrod L, Fried T, Marom N, Ramsay J, Weinstein-Evron M, Aharonovich S, Liphschitz N, Farhi Y, Yan X, Boaretto E. 2018b. Pigeon-raising and sustainable agriculture at the fringe of the desert: a view from the Byzantine village of Sa'adon, Negev, Israel. Levant. p. 1-23.

Trueman CN, Behrensmeyer AK, Tuross N, Weiner S. 2004. Mineralogical and compositional changes in bones exposed on soil surfaces in Amboseli National Park, Kenya: diagenetic mechanisms and the role of sediment pore fluids. Journal of Archaeological Science 31(6): 721-739.

Vaiglova P, Hartman G, Marom N, Ayalon A, BarMatthews M, Zilberman T, Yasur G, Buckley M, Bernstein R, Tepper Y, Weissbrod L, EricksonGini T, Bar-Oz G. 2020. Climate stability and societal decline on the margins of the Byzantine empire in the Negev Desert. Scientific Reports $10(1)$.

Varro MI. 1934. On agriculture. Hooper WD, translator. Cambridge (MA): Harvard University Press.

Ward GK, Wilson SR. 1978. Procedures for comparing and combining radiocarbon age determinations: a critique. Archaeometry 20(1): 19-31.

Weiner S, Bar-Yosef O. 1990. States of preservation of bones from prehistoric sites in the Near East: a survey. Journal of Archaeological Science 17(2):187-196.

Weiner S. 2010. Microarchaeology: beyond the visible archaeological record. Cambridge University Press.

Yizhaq M, Mintz G, Cohen I, Khalaily H, Weiner S, Boaretto E. 2005. Quality controlled radiocarbon dating of bones and charcoal from the early PrePottery Neolithic B (PPNB) of Motza (Israel). Radiocarbon 47(2):193-206.

Zohar M, Salamon A, Rubin R. 2016. Reappraised list of historical earthquakes that affected Israel and its close surroundings. Journal of Seismology 20(3):971-985. 